\title{
CREATIVE ADJUSTMENT OF LINGUISTIC AND TEXTUAL RESOURCES IN LITERARY TRANSLATION
}

\author{
Bal Ram Adhikari
}

The present article conceptualizes the process of rewriting the given text in the target language (TL) as regeneration of the text across languages. Shedding light on similarities and differences between producing a text across languages i.e. transwriting and within a language i.e. writing, it is argued that translation is a creative process almost exclusive to linguistic and textual levels.

Keywords: Manipulation, regeneration, transwriting, translational creativity

\section{Introduction}

Translation is a Janus-faced process of text production across languages which entails interpretation of the source text (ST) and its regeneration in the target language (TL). It requires the translator to read and re-read the ST so as to extract meanings and rewrite the extracted meanings in the TL. The translator is thus involved in twin processes of meaning extraction through reading, and regeneration of the text through writing. He/she takes on a dual role, as the reader of the ST and the writer of the TT. In other words, "besides being the reader of a text, the translator is also the writer of a text to be read by others" (Joseph, 1987: 109-110). Of these two processes involved in translation, the present article concerns the second one i.e. regeneration of the text.

From the perspective of writing, translation is a process of generating a text again in another language. The process can be called regenerating the text across languages, which in a number of ways, resembles as well as differs from generating the text within a language. Generating a text within a language, conventionally called writing, and regenerating the text across languages, which can be called transwriting, both are manipulative, regenerative, repetitive and creative. Writer and transwriter both are text producers in their respective languages. Both relay on and manipulate "diverse linguistic and cultural materials that neither the [...] writer nor the translator originates " (Venuti, 1995: 17-18). That is, both are only text shapers not originators of these materials. Thus, the outcome of generative process is derivative and unique at the same time.

Writing and transwriting both are processes of regenerating the text from already existent linguistic and cultural resources. No text is absolutely innovative nor is it the absolute replica of the text already in existence. That is, each text is repetitive and innovative at the same time. In this regard, Selden, Widdowson and Brooker, (2005) refer to Barthes' (1968) claim that writers only have power to mix already existing writing. They can only reassemble or reuse what others have already written. Barthes further claims that writers only draw on the immense dictionary of language and culture always already written. Likewise, Paz finds the distinction between original writing and transwriting blurred:

Every text is unique and, at the same time, it is the translation of another text. No text is original because language itself, in its essence, is already a translation: firstly, of the nonverbal world and secondly, since every sign and every phrase is the translation of another phrase. However, the inverse of this reasoning is also entirely valid. All texts are originals because each translation has its own distinctive character. Up to a point, each translation is a creation and thus constitutes a unique text. (1971/1992:154)

Despite such resemblance, we can also discern some marked differences between writing and transwriting. The writer relies on varied textual and non-textual resources. He/she can use already published texts to draw content and even language for his/her work or can simply refer to them. Experiences, emotions, imagination and facts are nontextual resources of the text. The writer is free

Nepalese Linguistics, vol. 34, 2019, pp. 1-9. 


\section{2 / Creative adjustment of...}

to manipulate such resources. There is a single agent who determines content, context and form of the text. Finally, writing within a language is monolingual in nature. On the contrary, while regenerating the text across languages, the transwriter works on the single textual source of meanings and forms. Content, context and form are already fixed by the writer. In principle, the transwriter has no right to manipulate them willfully. Moreover, there are two agents involved in the regeneration of the text: writer and transwriter. Put differently, a translated text houses two creative souls. At this juncture, I quote from the translatorial 'Of being caught in a double-bind':

[...] while writing, I am monolingual, monocultural, unidirectional, and most of all I am confined to a single pragmatic compass, whereas while translating, I am acting to be overtly bilingual, bicultural (though it may be only for a limited degree and a certain period of time), two directional and more importantly I try to transcend the single pragmatic world to enter another one, which is alien to my language and culture. (Adhikari, 2010: vii)

It implies that bilingual regeneration of a text is more demanding than monolingual textual generation, for the former involves more constraints than the latter. Unlike the writer, the transwriter has to fulfill a two-way obligation to the ST, the source, and the target readers, the destination. Obligation to the source writer requires him/her to gravitate towards content and form of source message, whereas obligation to target readers requires him/her to be faithful to TL grammar and convention. It also requires the transwriter to be creative in terms of word choice, syntactic manipulation and textual organization.

Despite the fact the existent text serves as the source for the transwriter, it does not mean that he/she begins from where the ST writer ends. Rather, the transwriter (re)constructs the text anew and the process parallels the one followed by the ST writer. By regenerating the ST in the TL, the transwriter gives a new life or energy to the ST, or revitalizes it which otherwise would remain within the confinement of the SL. It is through regeneration that a text undergoes material or textual and spiritual transformation. A literary text is more than the objective information it carries because it "'posits man's physical and spiritual existence" (Benjamin, 1923/2000:15). The spiritual or subjective dimension of the text amounts to the authorial ego and creative soul and the reader's emotional responses to the overall text. The text after it undergoes cross-linguistic transformation embodies authorial egos and creative souls of writer and transwriter. As a result, the translated text acquires material and spiritual dimensions different from those of the ST. Lastly, it is the transwriter who gives rebirth to the ST as a TT that speaks a different tongue. The transwriter's role thus turns out to be that of the procreator.

Drawing on these theoretical arguments, the present article aims to explore different dimensions of regeneration of text. The term 'regeneration' is used as an alternative to such heterogeneous terms as "reproduction" (Nida, 1964), "rewriting" (Lefever, 1992), and "transcreation" (Mukherjee, 1994; Singh, 2010).

\section{Method}

The present article draws on tenets of productoriented research that studies the textual product that is the outcome of the translation or interpretation process (Saldanha \& Breen, 2013:50). Of the different approaches available in this research methodology, I have employed a descriptive and explanatory approach to the analysis of the translation as a product. The cases were sampled purposively from the novels sukarāt-kā pāilā (Bhattarai, 2063 B.S.) and its English translation Socrates' Footsteps (2010), anido pahād-sangai (Parijat, 2073 B. S.) and its English translation Under the Sleepless Mountain (2007), and a Nepali essay rendered by a novice translator. The cases in Nepali are transliterated in English Roman followed by their English translations.

\section{Analysis and discussion}

This section presents the purposively selected cases and their analysis under the thematic headings of mechanical reproduction vs creative reproduction, regeneration as creative linguistic activity in terms of word choice, syntactic 
manipulation and text organization. These themes are principally informed by theoretical insights generated from Wilss (1994), Singh (2010) and Frankenberg-Garcia (2017).

\subsection{Mechanical reproduction vs creative adjustment}

Regeneration is a process of rewriting of the ST in the TL. However, this process is more than mechanical reproduction of the text across languages. Rather, it is creative adjustment of ST elements in the TL that shows the transwriter's ability to compose a literary text in the TL, using materials extracted from the ST. The following cases serve to illustrate key differences between mechanical reproduction and creative adjustment:

Case 1

ST (Nepali): hāmi jaba aglo pahāḍ-muni-ko unko ramāilo ghar najikai pugyaũ, rāto, nilo ra seto ray-ko jhanḍā hāwā-mā pharpharāirahe-ko thiyo. sāth-mā yātrā garirahe-ki runā-le ma-tira herera bhanin, "yo timro swāgat-ko lāgi rākhieko ho". agli kadh ra anuhār-mā camak bokeki, seto kapāl tara akhā-ma gājal lagāeki bențe hāmi-lāi lina ghar bāhir niskin.

TT (English): As we arrived near her beautiful home at a lofty hill, there was a large red, blue and white colored flag fluttering delightfully. Runa, the co-traveler, turned to me and said, 'it is set to welcome you. A tall statured and dazzling faced, with white hair but kajal decorated eyed Bente came out from her home to welcome us.

It is an extract from a travelogue rendered by a novice literary translator. The extract typifies the mechanical reproduction of the Nepali text in English. The translator has literally reproduced the ST, which has resulted in a syntactically unwieldy text in English. The English text is dictated by the ST in terms of word order and textual organization. In the translation of the expression rāto, nilo ra seto ray-ko jhandā (literally: a large, red, blue and white colored flag), for example, the translator has stacked five adjectives before the noun almost in the same order as they occur in the ST. Unlike in Nepali, "stacks of more than three adjectives rarely occur" in English (Cowan, 2008: 238). Also, the translator's priority to linearity has marred readability and fluidity of the text. That is, the translator has attempted to follow the ST structure closely. Consequently, there is heavy presence of Nepali structure in the English text. The expressions such as As we arrived near her beautiful home at a lofty hill and $A$ tall statured and dazzling faced, with white hair but kajal decorated eyed Bente are the clear indicative of the translator's failure to use his creative license to produce a readable text in English. To follow Nida's (1964:185-187) framework of literary translation, this translator is confined to the stage of minimal transfer which involves mechanical reproduction of the ST, yielding the unrefined version. Let us compare the above translation with the following version:

TT (English: Creative adjustment): As we arrived near her beautiful house at the foot of a lofty hill, a large red, blue and white flag fluttering delightfully came to our sight. Runa looked at me and said, 'It is hoisted here to welcome you". There turned up a tall lady with white hair, kajal in her eyes. She was Bente, who welcomed us with her beaming smile. (My translation)

This extract reveals the translator's attempt to move beyond the stages of literal translation and minimum transfer, and make the text literary to the extent possible. We can see several instances of creative adjustment of the ST in the TT. Let us take some of them. The word ray-ko (colored/ having color) has been removed from the TT because its use with color adjectives red, blue and white is redundant. Its removal also helps to reduce the number of adjectives before the noun jhand̄a (flag). Likewise, house is used in place of home, because, as suggested by the context, the speaker is referring to the building, and pahādmuni (literally: under the hill) has been rewritten as at the foot of the hill. The complex subject NP agli kadh ra anuhār-mā camak bokeki, seto kapāl tara akhā-ma gājal lagāeki bente (literally: a tall statured and dazzling faced, with white hair but kajal decorated eyed Bente) has been thoroughly restructured in English as a tall lady with white 
4 / Creative adjustment of...

hair, kajal in her eyes. She was Bente, who welcomed us with her beaming smile.

Compared to the novice translator's text, this translation reads natural in English. The translator has regenerated the ST in the TL, obeying its grammar rules and discourse principles. He has maintained linearity to ensure the TT's fidelity to the ST in terms of content and style without compromising on his fidelity to the TL system. There is presence of foreignness in content (e.g. kajal), but not in sentence construction. Addition, deletion and permutation of words reveal the translator's awareness of judicious use of creative license in literary translation. Finally, the translator presents himself as a re-creator rather than the mere rewriter of the ST in the TL.

\subsection{Regeneration as a creative linguistic activity}

Creativity in translation is a debatable and long debated issue. Bayer-Hohenwarter conceptualizes translational creativity as the translator's "ability to depart from the source text (ST) structure by applying creative shifts" (2011: 663) such as addition, modification, permutation and deletion. This notion of creativity implies that creative translators are aware of the fact that there is no one-to-one correspondence between SL and TL and hence any attempt to reproduce the text in the TL would yield an unacceptable translation. The TT certainly departs from the ST in many respects at different levels of texts ranging from vocabulary to discourse organization. However, we should not forget that departure is not the sole criterion for assessing creativity in translation, for the TT should not divert too far from the form and content of the ST. Put simply, there should be some correspondence between TT and ST at a deeper level. It implies that translation involves enactment of creativity within the constraints imposed by the ST as well as TL system. It is on this ground that Wilss (1994) argues that translation is not a genuinely creative process. Wilss further maintains that "strictly speaking, translation is not a creative, but rather a creative linguistic activity. Translation is never a creatio ex nihilo, but the reproduction of a given SL text, combining a comprehensive and an inventive phase of textually-bound behavior" (1994: 4750). Translation is thus creatio ex materia, that is, the starting point of translator's creative writing is the fixed text, "not the language in movement that provides the poets raw material" (Paz, 1971/1992:159). Furthermore, Wilss' (1994) observation limits translational creativity to the linguistic dimension which gets reiterated in Singh's (2010) conceptualization of creativity as "a rearrangement of existing signs. Creativity is a point of view to look at the world which is already in existence, and yet defining it in new permutations and combinations p.46)". Thus, we can argue that translation involves creativity within textual captivity. Here I once again quote from the translatorial:

One of the questions often raised in literary translation is concerned with the translator's creative license. To what extent are translators free to play with the source text? [.... Can they rewrite freely what they have interpreted? It seems to me that literary translators enjoy freedom within their self-chosen captivity. Creatively. Consciously and painfully. Hence, literary translation turns out to be creativity within captivity which I found rather challenging and at times rather frustrating. (Adhikari, 2010: ix)

The transwriter's creativity is predominantly confined to the linguistic aspect, for content and structure of the text are already specified by the writer. Moreover, even linguistic creativity has to be within the compass of vocabulary, grammar and style of the given text. It means while regenerating the $\mathrm{ST}$ in a new form in the TL, the transwriter is bound to be within the captivity of content, language and form of the existent text. It is the process of generating a new text from the given one. During this regenerative process, the transwriter can demonstrate his/her creativity in different areas of the text and at different levels of language.

\subsubsection{Word choice}

Creativity begins with reading of the ST. Creative reading is a prerequisite for regeneration of the given text in a novel form in the TL. Creative reading requires the transreader to comprehend multiple layers of meanings of words, create different images for them and decide on the most fitting TL words for the images. In other words, 
the transreader is often required to transcend denotative meanings and dig into the text in order to explore connotative meanings implied by the context or the meanings intended by the speaker. The following extracts serve to illustrate this theoretical stance:

Case 2

ST (Nepali): āphno koṭhā-mā puge-pachi ananta dherai-bera-samma cintā-mā dubirahyo. ke ma eutāa byakti mātra hun? ma āphno bhāgya-nirmān gari-rahana swtantra chu? malai mero pariwes-le sahyog garnu pardaina? (Bhattarai, 2063, B.S.:31 )

TT (English): Back to his room, Ananta sank into gloom for long. "Am I merely an individual? Am I really free to craft my destiny? Shouldn't my surroundings help me? (Bhattarai, 2010: 33)

The TT in Case 2 exhibits some instances of creativity in word choice. Let us take two chunks cintā-mā dubi-rahyo (literally: kept sinking in anxiety) and āphno bhāgya-nirmān gari-rahana (literally: to make one's fate). The translator has shunned the denotative meaning of the word $\operatorname{cint} \bar{a}$ as anxiety and preferred the contextually suggested meaning gloom. In fact, the lines above suggest the sense of helplessness and hopelessness that the protagonist experiences in the unfeeling and inhospitable city of Kathmandu. Anxiety is thus too shallow to capture the psychological state of an innocent country boy who finds himself awfully lonely in the city. Likewise, the second chunk, if translated literally, would read like this-Am I free to make my fate? which might convey the surface meaning but not the meaning intended by the author, nor would it sound so literary. The word bhāgya mainly means fate and it also means destiny, which can be translated back into Nepali as niyati. The author's intended meaning is destiny not fate because it is an existential novel which mainly draws on Sartre's existentialism. Sartre used destiny not fate while taking about man's existence as "the destiny of man is placed within himself" (1946) with the philosophical message that man makes himself. There is another reason for choosing destiny over fate. Fate implies something already decided, it is the past that an individual cannot change, forget making or crafting it, whereas destiny is the future, which, if a person strongly wills, can be changed. It means we can craft destiny, not fate. Here is another example of creative word choice:

\section{Case 3}

ST (Nepali): tyo sãjh-mā ananta-le eklai socirahyo-jivan nikai bhitra pugecha. tyo anyol mārga-mā. pharkane dobāțā-haru sochyo, tara man-mā ti āenan. aghi baḍhne gorețo-tira driți lagāyo, ti prasta dekhienan. (Bhattarai, 2063, B.S.:31 )

TT (English): That evening Ananta, all on his own, was sinking in thought. "My life has reached deep in this labyrinthunawares". He thought about the paths to retreat, but his mind got no trace of any of them. He cast his eyes over the paths ahead only to find them lost in haze. (Bhattarai, 2010: 41)

The underlined Nepali chunks have been recreated in English. The verb pugecha (literally: it has reached without my knowledge) calls for creative adjustment in English because it is in the unknown past, which is absent from English grammar. It means the action happened in the past and the agent is aware of it now. To convey this meaning ingrained in the verb, the translator has added the word unawares in the English text. Another chuck anyol mārga-mā (literally: on the unknown path) has been recreated as in this labyrinth. The contextually recreated word labyrinth is preferable to the mechanically reproduced chunk the unknown path because the former is more visual than the latter and concretizes the protagonist's predicament. Moreover, labyrinth reads more literary, lexically more expressive and hence contextually more fitting than the mechanically reproduced chunk. Finally, the contextually recreated chunk for $t i$ prasta dekhienan (literally: they were not seen clearly) reads them (i.e. the paths) lost in haze. The ST implies the lack of clarity in the life of the protagonist who finds himself in a quandary and fails to decide what to do and where to go. Lost in haze is figurative and more expressive than the literally reproduced expression they were not seen clearly. It suggests that the transwriter is inclined 
6 / Creative adjustment of...

to the use of elevated diction. However, it is imperative that the transwriter use his/her creative license with caution. In this regard, he/she should heed Belloc's rule of thumb, "The translator should never embellish" (as cited in Bassnett, 2002:121). That is, while playing with words, the transwriter's aim should not be to decorate the TT by imposing literary diction from his/her side. The aim instead should be to make contextually implied meaning more expressive in the TT. Put differently, the transwriter should use figurative and expressive words only to release the meanings suppressed in the ST and make the author more articulate in the TT.

While playing with words creatively, translators should read not only the lines, but also between the lines and beyond the lines. Reading the lines is a prerequisite for understanding denotative or literal meanings of the text. Reading between the lines helps the translator to grasp connotative, intended or contextual meanings, whereas reading beyond the lines helps him/her to work out cultural meanings of words.

\subsubsection{Syntactic manipulation}

Singh defines creativity as "new permutations and combinations" ((2010: 46). Translational creativity can thus be defined as the different ways of arranging words and combining sentences in the text so as to arouse dramatic effect in readers. The transwriter can manipulate words within a sentence, and sentences across their boundaries. Syntactic manipulation involves, among others, permutation of word order, sentence-joining and sentence-splitting. These syntactic operations bring about shifts in word order and structures of sentences. Sentencesplitting involves the change of sentence boundaries by rendering one sentence with two or more, whereas sentence-joining renders one sentence into two or more sentences (Frankenberg-Garcia, 2017). Permutation refers to the process whereby the transwriter changes source word order in the TT.

Transwriters normally tend to take a sentence as a unit of translation (Newmark, 1998). Accordingly, they often translate sentence by sentence, maintaining syntactic parallelism between ST and TT. However, they should feel free to split or join sentences when complex and compound sentences need to be split into simple sentences for clarity, or combine simple sentences to tighten them up in the TT.

Sentence-joining and sentence-splitting reflect creativity in textual regeneration at the syntactic level. Rather than slavishly following sentence boundaries of the ST, the transwriter can join simple sentences to form complex or compound sentences or split complex or compound sentences into simple ones or even extract a chunk from the sentence and rewrite it as a clause or simple sentence. The use of such syntactic operations across sentences, however, should be contextually justified. The transwriter should take care of the writer's style before employing these operations. Consider the following extract from Parijat's anido pahād-sangai and its English translation Under the Sleepless Mountain:

Case 5

ST (Nepali): purwi nepāl-mā janmeki candrakāntā-le āphno agyān awasthā-mā nai pariwār-sanga muglān pasnu paryo. muglān-mā durgati bhayo, țuhuri bhai, ekli bhai, dukha pāi, pacāsaun hanḍar khāera taruni bhai, thupraithuprai logne-māch-haru-le us-lāi sosan gare, hepe. (2073 B. S. : 22)

TT1 (English): Chandrakanta [...] was born in eastern Nepal and had had to migrate to India to seek employment at a very early age. There in India, as an orphan girl, she had been exploited and dominated. She had experienced many misfortunes in life, and yet she had grown up into a lovely young woman. (Parijat, 2007:27)

This translation evinces two types of syntactic manipulation. The first involves rewriting of a phrase as an independent clause and the second is merging of independent clauses into a complex sentence. As to the first type, the transwriter has separated the infinitival phrase purwi nepāl-mā janmeki (literally: born in the eastern Nepal) from the sentence and rewritten it as an independent clause as Chandrakanta was born in the eastern Nepal. Moreover, the first simple sentence is split into a compound sentence coordinated by and. Here, the transwriter is inclined to the 
simplification process. The rest of the sentences have undergone the reverse syntactic operation i.e. joining or merging of clauses. Consequently, English sentences read more complex than their source counterparts. There are seven short sentences (or independent clauses) separated by commas, which have been written as two compound sentences. Moreover, the independent clause tuhuri bhai (literally: she became an orphan) has been reduced to a verbless clause as an orphan girl. This extract reveals the use of creative license in the regeneration the ST in the TL. Despite this, the free manipulation of source sentences in the TL is questionable. First, this translation stresses the content at the expense of the structure of the ST. The use of short and simple sentences (independent clauses) in the ST seems to be stylistically motivated, and the structural shift has caused shift in the author's style. In principle, the transwriter is not supposed to distort the style that the writer has used in the text. Source sentences are fast-flowing, energetic and draw readers' attention to different untoward events happened to the protagonist one after another. Consider the following translation of the second sentence:

TT2 (English): She lived a wretched life in the foreign land; she became an orphan; she came of age, suffering all sorts of adversity; many a man exploited her, oppressed her, bullied her. (My translation )

This translation stresses both content and structure of the ST. Seven simple sentences or independent clauses have been rewritten as six sentences, separated by semi-colons. There is one instance of sentence-joining wherein the fourth sentence has been reduced to a free adjunct (suffering all sorts of adversity). The purpose of comparing TT1 and TT2 is to shed light on the fact that the transwriter should manipulate structures of sentences only when it is necessary to break or join the sentences.

\subsubsection{Text organization}

Text stands for a group of sentences which are linguistically cohesive and semantically coherent. It requires translators to possess linguistic creativity i.e. awareness of how linguistic and textual resources can be best handled to produce the text that achieves the rhetorical goals intended by the ST. Textual resources subsume mainly thematic structure, rhetorical structure and informational structure. It also requires the transwriter to use the linguistic devices such as reference, substitution and ellipsis, conjunction (Baker, 2011). Composing a cohesive text in the $\mathrm{TL}$ is a daunting task even for experienced translators, let alone novices. It becomes more daunting mainly when we are translating from the mother tongue to the other tongue. Consider the following English translation and its Nepali source to see the translator's manipulation of linguistic and textual resources:

Case 6

ST (Nepali): tuwālo lāgnu-parne chyānga tārāmanḍal dekhincha. chyānga hunu-parne rātmā huri calcha. khai ke bhayo ke bhayo samaya sāl . man-man-mā dohoryāudai ghyabarin buḍā-le ekpalța ākās-tira heryo ra sulphā tānyo. ākās-mā kālā bādal-kā lolā-haru maḍaridai thie, hāwā narāmro-sãnga ghisriera calirahe-ko thiyo. ghar cheuchāukā amliso ghāri, kewãrā-kā jhāy-haru syārsyārti bajthe. yo ekāki buḍā-ko man jastai birāno thiyo. (Parijat, 2073 B. S.:5)

TT (English): Deeply absorbed in thought, Ghyabring, an old man, looked up at the sky while smoking his pipe, "What an unpredictable time of year!" he thought. "The sky is filled with twinkling stars instead of being misty, and then the wind blows and clouds gather suddenly, when the sky should be clear."

Clouds covered the sky, the wind was really howling. Around the houses, brown pine shrubs, twisted into screw shapes by years of wind, were stirring. But the night seemed like a friendly stranger in his loneliness. (Parijat, 2007: 9)

This is an extract from the opening paragraph of the novel, which, when compared with the ST, reveals the transwriter's free manipulation of source linguistic and textual resources in the TL. Here are some of the pieces of evidence to attest this observation. First, the single paragraph has been presented into two paragraphs in English. Second, the sentences in the ST are rearranged in the TT. The first sentence, for example, tuwālo 
8 / Creative adjustment of...

lāgnu-parne chyānga tārāmanḍal dekhincha (literally: The sky is open and starry when it is supposed to be hazy) appears at the end of the first paragraph (The sky is filled with twinkling stars instead of being misty), whereas the English translation opens with the third sentence of the Nepali text i.e. man-man-mā dohoryāudai ghyabariy buḍa-le ekpalța ākās-tira heryo ra sulphā tānyo (Deeply absorbed in thought, Ghyabring, an old man, looked up at the sky while smoking his pipe).Third, the transwriter has introduced inverted commas in the English version to present the character's monologue. Fourth, there are cases of merging of two Nepali sentences into single English sentences. Consequently, the English text reads more complex than its Nepali counterpart in terms of textual organization. Fourth, there are more cases of coordinating and subordinating in the TT than in the ST.

At the textual level, the transwriter has taken the content from the ST and rewritten it almost freely in English. Otherwise stated, the ST is broken and reorganized in the TL. At this juncture, one may raise a question as to this type of manipulation of ST in the TL- To what extent is the transwriter free to bring about shifts at the textual level? There is no definite answer to this question. However, the transwriter should awaken to the fact that he/she is free, but not too free to deviate from the ST organization. Such deviation might distort the writer's style and rhetorical goals. Any textual level shift should be justified by the context. Wherever we come across the shifts, we can ask the questions- Is it because the ST is not coherently organized? Is it because the translator thinks that the ST needs to be reorganized in the TL to ensure better communication with the readers? Viewed from this perspective, the shifts in the above translation do not seem so justifiable.

\section{Conclusion}

More than the reproduction of surface form and meaning of the ST, literary translation is a complex process of regenerating the given text in a novel form that involves the analysis of layers of meaning and rewriting them in the TL. During the regenerative process, the given text undergoes mutation, particularly at linguistic and textual levels. Freeing oneself from mechanical reproduction, the transwriter has to adjust the ST creatively in the TL, which calls for, among others, addition, deletion and permutation. Moreover, the transwriter often comes up with a number of alternative words in the TL for the single source word. In such a situation, he/she has to take into account of denotative and connotative meanings of words and choose the target word that closely matches the meanings objectively conveyed by the words and subjectively implied by their context. The textual regenerative process is also characterized by shifts at syntactic and textual levels. Syntactic shifts can be brought about by means of syntactic operations such as sentence-joining and sentence-splitting, whereas ST clauses or sentences can be arranged in different order to bring out textual shifts. It means the transwriter can use his/her creative license to manipulate source linguistic and textual resources. However, while manipulating, he/she should not deviate from the content, style and rhetorical goal of the ST.

\section{References}

Adhikari, Bal Ram. 2010. Of being caught in double-bind. In Govinda Raj Bhattarai, Socrates' footsteps (Trans. Bal Ram Adhikari) (pp.vii-xii). Kathmandu: Oriental Publication.

Baker, Mona. 2011. In other words: A coursebook on translation. London and New York: Routledge.

Bassnett, Susan. 2002. Translation studies (2nd ed.). London and New York: Routledge.

Bayer-Hohenwarter, Gerrit. 2011.Creative shifts as measuring and promoting translational creativity. Meta: Translators' Journal, 3, 663-691.

Benjamin, Walter. 1923. The task of the translator. In Lawrence Venuti (Ed.) (2000), Thetranslation studies reader (pp. 15-25). London and New York: Routledge.

Bhattarai, Govinda Raj. 2063 B. S. sukarāt-kā pāilā [Socrates' footsteps]. Kathmandu: Modern Books.

Bhattarai, Govinda Raj. 2010. Socrates' footsteps [Trans. Bal Ram Adhikari]. Kathmandu: Oriental Publication. 
Cowan, Ron. 2008. The teacher's grammar of English. Cambridge: Cambridge University Press.

Frankenberg-Garcia, Ana. 2017. A corpus study of splitting and joining sentences in translation Corpora. Guildfor: Surrey Research Insight.

Joseph, G. 1987. Translation, reading and literary theory (Doctoral dissertation). Indiana University.

Lefever, Andre. 1992. Translation/history/culture. London \& New York: Routledge.

Mukherjee, Sujit. 1994. Translation as discovery.Hyderabad: Orient Longman.

Newmark, Peter. 1998. A textbook of translation. Hertfordshire: Prentice Hall Europe.

Nida, Eugine. 1964. Toward a science of translating. Leiden: E. J. Brill.

Parijat. 2007. Under the sleep less mountain [Trans. Nara Pallav]. Vanarai: Pilgrims Publishing.

Parijat. 2073 B. S. anido pahād-sangai [Under the sleepless mountain] (2nd ed.). Kathmandu: Phinix Books.

Paz, Octavio. 1971/1992. Translation: Literature and letters (trans. I. d. Coral). In R. S. (Eds.),Theories of translation: An anthology of essays from Dryden to Derrida (pp. 152-62). Chicago: The University of Chicago Press.

Saldanha, Gabriela. \& O'Brien, Sharon. (2013). Research methodologies in translation studies London and New York: Routledge.

Selden, Raman. Widdowson, Peter. \& Brooker, Peter (2005). A reader's guide to contemporary theory (5th ed.).Harlow: Pearson Longman.

Singh, Udaya Narayan. (2010). Translation as growth. Delhi: Pearson.

Wilss, Wolfram. (1994). Translation: Process and procedures . In Ron Asher, The encyclopedia of language and linguistics (pp. 4747-4756). Oxford: Pergamon. 